\title{
THE ROLE OF GOVERNANCE ON INWARD FOREIGN DIRECT INVESTMENT IN DEVELOPING COUNTRIES
}

\author{
Adem GÖK $K^{[*]}$ \\ A. Suut DOĞRUEL ${ }^{[*]}$
}

\begin{abstract}
Developing countries generally have poor governance infrastructure negatively affecting investment climate. Since economic growth of host countries is another important factor affecting the foreign direct investment decisions, the aim of the paper is to analyze the effect of governance infrastructure and economic growth with other control variables on FDI inflows in developing countries and to discuss policy implications to increase their FDI inflows. Since governance, FDI and growth are three concepts that interact with each other according to the theoretical and empirical literature, System GMM methodology is used to deal with endogeneity problem. It is found that improvements in governance and higher GDP growth rate attract more FDI inflows in developing countries.
\end{abstract}

Keywords: Governance, FDI, System GMM Analysis.

JEL Classification: C33, F21, O57, P48

\section{GELIŞMEKTE OLAN ÜLKELERDE YÖNETIŞ̧IMIN GELEN DOĞRUDAN YABANCI SERMAYE YATIRIMLARI ÜZERINDEKİ ROLÜ}

\section{Özet}

Gelişmekte olan ülkeler genellikle, yatırım ortamını olumsuz etkileyen yetersiz yönetişim yapılarına sahiptir. Ayrıca, ülkelerin ekonomik büyüme oranları yabancı sermaye yatırım kararlarını etkileyen diğer önemli bir faktör olduğundan dolayı çalışmanın amacı, gelişmekte olan ülkelerde yönetişim altyapısının ve ekonomik büyümenin diğer kontrol değişkenleriyle birlikte doğrudan yabancı sermaye girişleri üzerindeki etkisini incelemek ve bu ülkelere yapılan doğrudan yabancı sermaye yatırımlarının arttırılabilmeleri için uygun politikaları tartışmaktır. Yönetişim, doğrudan yabancı sermaye yatırımları ve büyüme, teorik ve ampirik literatüre göre, birbirini karşıllklı etkileyen kavramlar olduğundan, Sistem GMM metodu kullanılmıştır. Yönetişimdeki iyileşmelerin daha yüksek bir gayri safi yurtiçi

${ }^{[*]}$ Corresponding Author, Res. Assist. Dr., Kırklareli University Department of Economics, Kayalı Campus, Kırklareli, adem.gok@klu.edu.tr

[**] Prof. Dr., Marmara University Department of Economics, Goztepe Campus, Istanbul, suut.dogruel@marmara.edu.tr 
hasıla büyümesinin gelişmekte olan ülkelere daha yüksek miktarda doğrudan yabancı sermaye yatırımı çektiği bulunmuştur.

Anahtar Kelimeler: Yönetişim, Sistem GMM Analizi.

JEL Sınıflaması: C33, F21, O57, P48.

\section{Introduction}

There are several benefits that the host countries derive from foreign direct investment (FDI) inflows. First of all, "FDI is more conducive to long-run growth and development than other forms of capital inflows" ${ }^{1}$ since FDI is a major source of technology and know-how. FDI enables knowledge and technology spillover from foreign firms to domestic firms ${ }^{2}$. FDI also has the potential of job creation and employment in the host country ${ }^{3}$. FDI "assists human capital formation, contributes to international trade integration, helps to create a more competitive business environment" ". In time of economic crises that the host country faces, FDI is less inclined to run away than other forms of capital inflows, since it has affiliates in the host country and more involved in the business environment of the host country ${ }^{5}$. Hence, the increased proportion of foreign investment in the form of FDI makes host country less vulnerable to rapid capital outflows in time of crises. Finally, FDI is an important source of financing the current account deficit 6 .

The effect of governance on FDI inflows is firstly through the effect of institutions on investment environment of a country and secondly through the decreasing transaction costs, production costs and uncertainty ${ }^{7}$. Because the investment environment of a country affects both domestic and foreign investors, and because foreign direct investment (FDI) has been shown to promote host country efficiency, it is a natural extension of the literature to consider the impact of governance infrastructure on cross-country differences in FDI flows" ${ }^{8}$.

The economic growth of the countries is also another important factor that affecting the foreign direct investment (FDI) decisions of multinational corporations along with governance quality. Hence the aim of the paper is to analyze effect of governance structure and economic growth on FDI inflows in developing countries with other control variables and to discuss policy implications

1 J. P. Walsh and J. Yu, "Determinants of Foreign Direct Investment: A Sectoral and Institutional Approach", IMF Working Paper, WP/10/187, 2010, p.3.

2 Walsh and Yu, Ibid.

3 C. Jude, and M. I. Silaghi, "Foreign Direct Investment, Employment Creation and Economic Growth in CEE Countries. An Open Issue”, Development, Energy, Environment, Economics, 1998, pp.352-356.

4 OECD, Foreign Direct Investment for Development, OECD Publications Service, 2002.

5 M. Busse, and C. Hefeker, "Political Risk, Institutions and Foreign Direct Investment", European Journal of Political Economy, Vol.23, No.2, 2007, pp. 397-415.

6 Jude and Slaghi, Ibid.

7 S. Bellos, and T. Subasat, "Governance and Foreign Direct Investment: A Panel Gravity Model Approach", International Review of Applied Economics, Vol.26, No.3, 2012, pp.303-28.

8 S. Globerman, and D. Shapiro, "Global Foreign Direct Investment Flows: The Role of Governance Infrastructure", World Development, Vol.30, No.11, 2002, p.1899. 
for these countries to increase their FDI inflows. Governance, FDI and growth interact with each other according to the theoretical and the empirical literature. Hence it is not possible to define a one-way relationship between them; instead there are two-way relationships between any pair of them. Due to this fact, System GMM methodology is used to deal with endogenity problem.

Next section presents conceptual background, empirical survey is in third section, and fourth section explains aggregate governance indicators used in the study. Data used in the study are explained in fifth section. Statistical analysis is carried out in sixth section. Seventh section presents both empirical methodology and empirical analysis of the study. Policy discussions are presented in the conclusion.

\section{Conceptual Background}

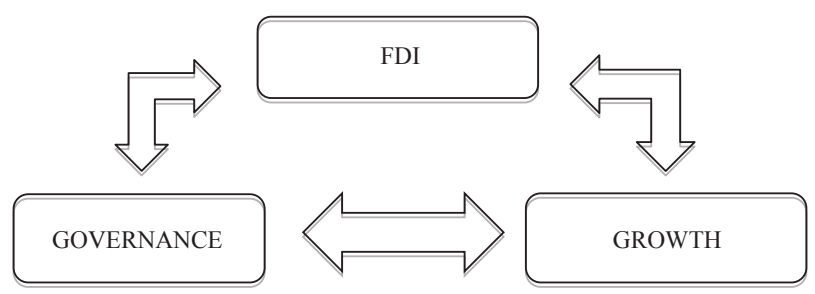

Governance, FDI and growth interact with each other according to the theoretical and the empirical literature. Hence it is not possible to define a one-way relationship between them; instead there are two-way relationships between any pair of them.

The impact of FDI on growth is expected to be twofold; (1) through the capital accumulation in the recipient economy, FDI is expected to be growth-enhancing by encouraging the incorporation of new inputs and foreign technologies in the production function of the recipient economy, (2) through knowledge transfers, FDI is expected to augment the existing stock of knowledge in the recipient economy through labor training and skill acquisition, on the one hand, and through the introduction of alternative management practices and organizational arrangements, on the other ${ }^{9}$.

Market-enhancing governance focuses on the role of governance in reducing transaction costs to make markets more efficient. Growth-enhancing governance focuses on the role of governance in enabling catching up by developing countries in a context of high-transaction cost developing country markets. In particular, it focuses on the effectiveness of institutions for accelerating the transfer of assets and resources to more productive sectors ${ }^{10}$.

Poor governance structure negatively affects the investment climate ${ }^{11}$ of the countries. In the literature, it is widely accepted that low quality of governance increases economic uncertainties

9 L.R.De Mello, and M. T. Sinclair, “Foreign Direct Investment, Joint Ventures, and Endogenous Growth”, Discussion Paper, Department of Economics, University of Kent, 1995.

10 M. H. Khan, "Governance, Economic Growth and Development since the 1960s", DESA Working Paper No. 54, 2007.

11 A. F. Aysan, M. K. Nabli, and M. A. V. Varoudakis, "Governance and Private Investment in the Middle East and 
and cost of doing business ${ }^{12}$, leads to partial, inequitable and inconsistent legal system which is unable to protect private property, rises political uncertainties due to civil disobedience or internal and external conflicts, and allows non-democratic practices of the governments in the form of unfair elections and electoral laws, absence of freedom of press, assembly and demonstration.

\section{Empirical Survey}

Instead of analyzing all the determinants of FDI in empirical literature, the study concentrates only on the literature about governance infrastructure as a determinant of FDI.

While, Globerman and Shapiro ${ }^{13}$, Sekkat and Varoudakis ${ }^{14}$, Busse and Hefeker ${ }^{15}$ found positive significant relationship between political stability and FDI, Asiedu ${ }^{16}$, Globerman and Shapiro ${ }^{17}$, Jadhav ${ }^{18}$ could not find a statistically significant relationship.

While Sekkat and Varoudakis ${ }^{19}$, Aseidu and Lien ${ }^{20}$, Cantah et al. ${ }^{21}$ found positive significant relationship between economic stability and FDI, Asiedu ${ }^{22}$ could not find a statistically significant relationship.

We will review the sub-indices of administrative quality. While Wei ${ }^{23}$, Habib and Zurawicki ${ }^{24}$, Globerman and Shapiro ${ }^{25}$, Globerman and Shapiro ${ }^{26}$, Busse and Hefeker ${ }^{27}$, found negative

North Africa”, CERDI, Etudes et Documents, E 27, 2006.

12 S. J. Wei, "How Taxing is Corruption on International Investors?", The Review of Economics and Statistics, Vol.82, No.1, 2000, pp.1-11.

13 Globerman and Shapiro, Global Foreign Direct Investment, Ibid.

14 K. Sekkat, and M. A. V. Varoudakis, Trade and Foreign Exchange Liberalization, Investment Climate, and FDI in the MENA Countries, World Bank, Middle East and North Africa, the Office of the Chief Economist, 2004.

15 Busse and Hefeker, Ibid.

16 E. Asiedu, "On the Determinants of Foreign Direct Investment to Developing Countries: Is Africa Different?", World Development, Vol.30, No.1, 2002, pp.107-119.

17 S. Globerman, and D. Shapiro, "Governance Infrastructure and US Foreign Direct Investment", Journal of International Business Studies, Vol.34, No.1, 2003, pp.19-39.

18 P. Jadhav, "Determinants of Foreign Direct Investment in BRICS Economies: Analysis of Economic, Institutional and Political Factor", Procedia-Social and Behavioral Sciences, Vol.37, 2012, pp.5-14.

19 Sekkat and Varoudakis, Ibid.

20 E. Asiedu, and D. Lien, "Democracy, Foreign Direct Investment and Natural Resources”, Journal of International Economics, Vol.84, No.1, 2011, pp.99-111.

21 W. G. Cantah, E. A. Wiafe, and A. Adams, "Foreign Direct Investment and Trade Policy Openness in Sub-Saharan Africa”, MPRA Paper, No.58074, 2013.

22 Asiedu, Ibid.

23 Wei, Ibid.

24 M. Habib, and L. Zurawicki, "Corruption and Foreign Direct Investment", Journal of International Business Studies, Vol.33, No.2, 2002, pp.291-307.

25 Globerman and Shapiro, Global Foreign Direct Investment, Ibid.

26 Globerman and Shapiro, Governance Infrastructure, Ibid.

27 Busse and Hefeker, Ibid. 
significant relationship between corruption and FDI, Egger and Winner ${ }^{28}$, Bellos and Subasat ${ }^{29}$, Bellos and Subasat ${ }^{30}$, Subasat and Bellos ${ }^{31}$ found positive significant relationship and finally Stein and Daude ${ }^{32}$, Jadhav ${ }^{33}$ could not find a statistically significant relationship. While Busse and Hefeker ${ }^{34}$ found positive significant relationship between bureaucratic quality and FDI, Bellos and Subasat ${ }^{35}$, Bellos and Subasat ${ }^{36}$ found negative significant relationship. Wheeler and Mody ${ }^{37}$ could not find a statistically significant relationship between administrative efficiency and FDI. While Globerman and Shapiro ${ }^{38}$, Globerman and Shapiro ${ }^{39}$, Mengistu and Ahdikary ${ }^{40}$ found positive significant relationship between government effectiveness and FDI, Jadhav ${ }^{41}$ could not find a statistically significant relationship.

We will review the sub-indices of public voice. While Busse and Hefeker ${ }^{42}$, Bellos and Subasat ${ }^{43}$ found positive significant relationship between democratic accountability and FDI, Bellos and Subasat ${ }^{44}$ could not find a statistically significant relationship. While Globerman and Shapiro ${ }^{45}$ found positive significant relationship between voice \& accountability and FDI, Jadhav ${ }^{46}$ found negative significant relationship and finally Globerman and Shapiro ${ }^{47}$, Mengistu and Ahdikary ${ }^{48}$ could not find a statistically significant relationship. Tuman and Emmert ${ }^{49}$ found positive significant relationship between political rights and FDI, civil liberties and FDI.

\footnotetext{
28 P. Egger, and H. Winner, "Evidence on Corruption as an Incentive for Foreign Direct Investment”, European Journal of Political Economy, Vol.21, No.4, 2005, pp.932-952.

S. Bellos, and T. Subasat, "Corruption and Foreign Direct Investment: A Panel Gravity Model Approach", Bulletin of Economic Research, Vol.64, No.4, 2012, pp.565-574. 


\section{Measuring Governance}

Reviewing the literature, all the studies examining role of governance on FDI based on either just one index like corruption, political stability, etc. or aggregate indices as Kaufmann et al. ${ }^{50}$, La Porta et al. ${ }^{51}$, etc.

As it can be seen in the previous section, different authors led to different conclusions based on countries included, data span, estimation techniques and governance indices used. There are both similar and contrasting results with respect to these differences. According to Globerman and Shapiro ${ }^{52}$, aggregate indicators like WGI developed by Kaufmann et al. ${ }^{53}$ drawn from a variety of sources should provide more precise measures of governance than individual indicators like corruption or political stability. It is possible to measure the effect of different aspects of governance on FDI inflows by this way. That's why four aggregate governance indicators created by sub-indices taken from ICRG and FRH databases used in the study.

Two aggregate indicators from WGI database; "political stability no violence" and "voice and accountability" will be analyzed for the robustness check of two aggregate governance clusters used in the study. The three governance indicators; political stability, administrative quality and public voice are based on governance indicators developed by Aysan et al. ${ }^{54}$. But, the reason to include these indicators, the motivation behind using them and the sub-indices of the indicators differs.

\section{I. Political Stability Index (PSI)}

This index is constructed to measure the safety of FDI due to political stability of the host countries.

Since the FDI decision of MNCs based on motivations and concerns different than short-term capital flows, politically unstable countries are not preferred as host countries for FDI. Because, the investment decision initiated by a typical MNC base on the plans for future profits through future sales of goods and services. If the host country, which initially is politically stable, turns into unstable either because of internal and external conflict, or the impaired government, FDI projects which seems profitable in the beginning turns into losses for MNCs. Hence, MNCs either decreases their FDI to that host country or shift their FDI altogether to other host countries that are politically more stable.

\footnotetext{
50 D. Kaufmann, A. Kraay, and M. Mastruzzi, "The Worldwide Governance Indicators: Methodology and Analytical Issues". Hague Journal on the Rule of Law, Vol.3, No.2, 2011, pp.220-246.

51 La Porta et al., Ibid.

52 Globerman and Shapiro, Global Foreign Direct Investment, Ibid.

53 Kaufmann et al., The Worldwide Governance Indicators, Ibid.

54 Aysan et al., Ibid.
} 


\subsection{Economic Stability Index (ESI)}

This index is constructed to measure the sustainability of FDI due to economic stability of the host countries.

Economic stability is another important aspect of governance, since MNCs consider the costs and returns on the FDI projects. If an economy is governed by inadequate and inconsistent economic policies and turns into unstable one, it constitutes the major cause of unpredictable high costs. Returns on FDI projects, which seem profitable at the beginning turn into losses mainly due to exchange rate risks and inflation. Bad economic governance increases uncertainty and risks, which are detrimental to FDI inflows. Hence MNCs either prefer economically more stable host countries or just make FDI if they predicted that the time required to exploit full return on FDI comes before the time of the economy in the host country becomes unstable.

\subsection{Administrative Quality Index (AQI)}

This index is constructed to measure the quality of the relationship between investor and the administrative / bureaucratic institutions of the host country, and the protection of investor rights.

MNCs taking FDI decision in a host country evaluates the performance of bureaucracy based on how responsive is the system to the need of investors, does it take too much time and effort even to initiate simple steps of investment plans, do investor have to deal with red tape. The bad quality of bureaucracy is a detrimental factor for FDI, since it increases the time for implementation of investment plans; hence it increases the costs of investment due to time lags.

Another important factor is the role of corruption in carrying out investment plans of MNCs. It increases the cost of FDI; hence it is a detrimental factor, unless MNCs corrupt the administration of host countries in order to access better terms or privileges.

MNCs also consider the protection against expropriation, contract viability by the risk of unilateral contract modification or cancellation, and payment delays by the extent that profits can be transferred out of the host country to home country bases. These sub factors define the investment profile of a host country and it constitutes an important role for MNCs taking FDI decision in a host country since they show the extent of protection of investor rights.

\subsection{Public Voice Index (PVI)}

This index is constructed to measure the protection of consumer rights against investors.

Democratic institutions "provide checks and balances on elected officials, which in turn reduce arbitrary government intervention and lowers the risk of policy reversal and strengthen private property protection" 55 . The type of products and services supplied by MNCs to domestic markets

55 Asiedu and Lien, Ibid, p.1. 
are highly sensitive to the preferences of consumers if the consumer rights in the host country are well protected. Any reduction in the quality of goods and services offered to domestic consumers is confronted with public reaction either by the legal system which provides those rights to consumers through lawsuits or by democratic actions through boycott, rallies, assembly against MNCs. Hence MNCs investing in these kinds of host countries take this reality into account at the planning stage of their investment. Increasing protection of consumer rights either through legal system or democratic rights of the public do not constitute a detrimental factor for FDI inflows in these countries. On the contrary, they enlarge the preference set of consumers, which lead to increased amount of FDI inflows by MNCs.

\section{Data}

Both statistical and empirical analysis cover thirty-two advanced, seventy developing and seventeen least developed countries for the period 1996-2010 due to data availability. See Appendix 2 for the source of data and methodology for the calculated indices.

\section{Statistical Analysis}

\section{I. Trend In FDI Inflows}

Figure I: Total FDI Inflows by Country Clusters

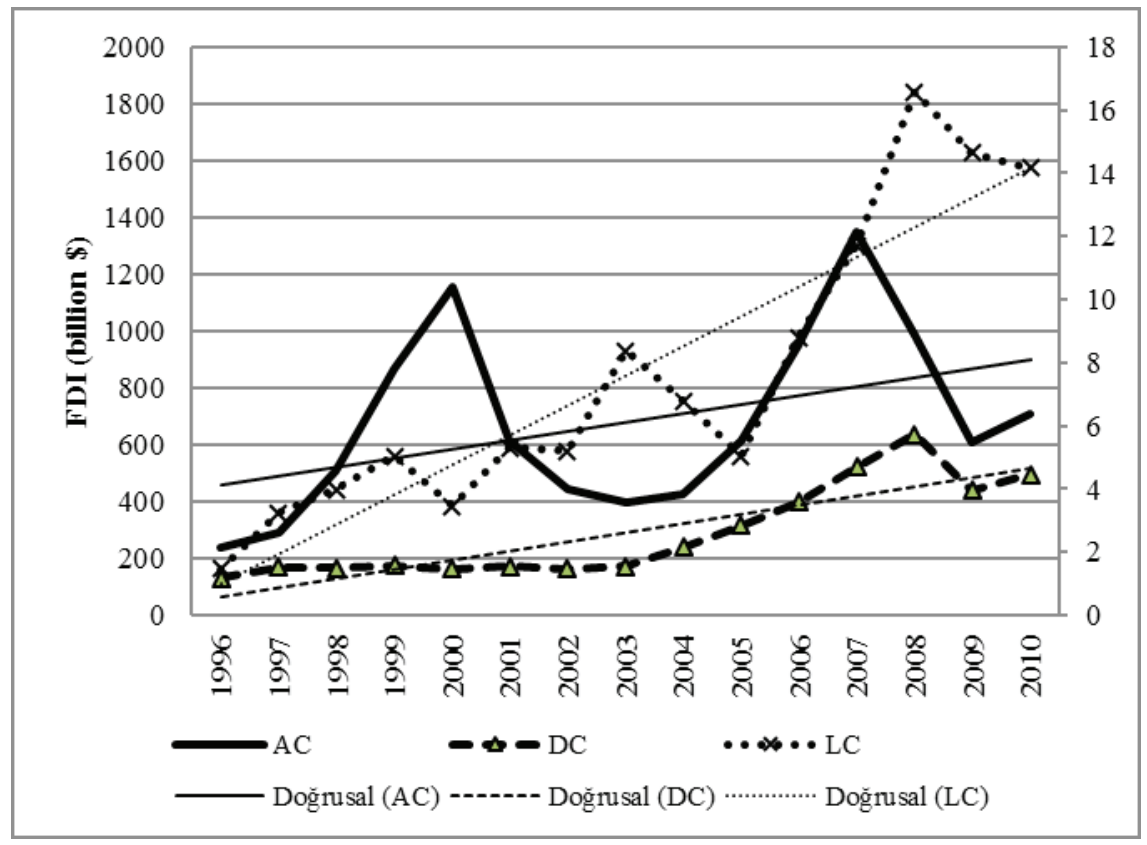

Source: Authors' Own Calculations 
Notes: The y-axis on the right for Least Developed Countries (LC). The y-axis on the left for advanced countries (AC), developing countries (DC) and for all countries taken together (ALL).

According to Figure 1, FDI inflows for all country clusters have been increased. According to the liner trend analysis, FDI inflows in developing and least developed countries increased more than advanced countries. Hence we can conclude that the share of advanced countries from FDI inflows have been declined while the share of developing and least developed countries have been increased.

\subsection{Trend in Governance Infrastructure}

Figure 2: Average PSI for DC

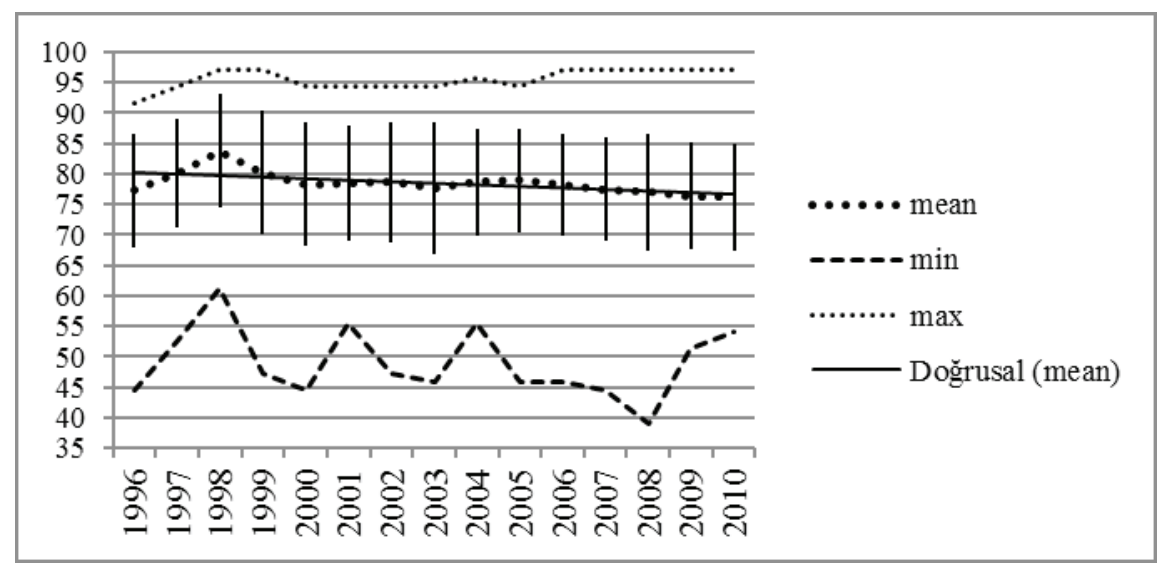

\section{Source: Authors' Own Calculations}

Average political stability of seventy developing countries has slight decreasing trend that decreased from 77 at 1996 to \% 76 at 2010 according to Figure 2. There is no significant trend in the standard deviation, hence we cannot conclude whether convergence or divergence is experienced in this country cluster. 
Figure 3: Average ESI for DC

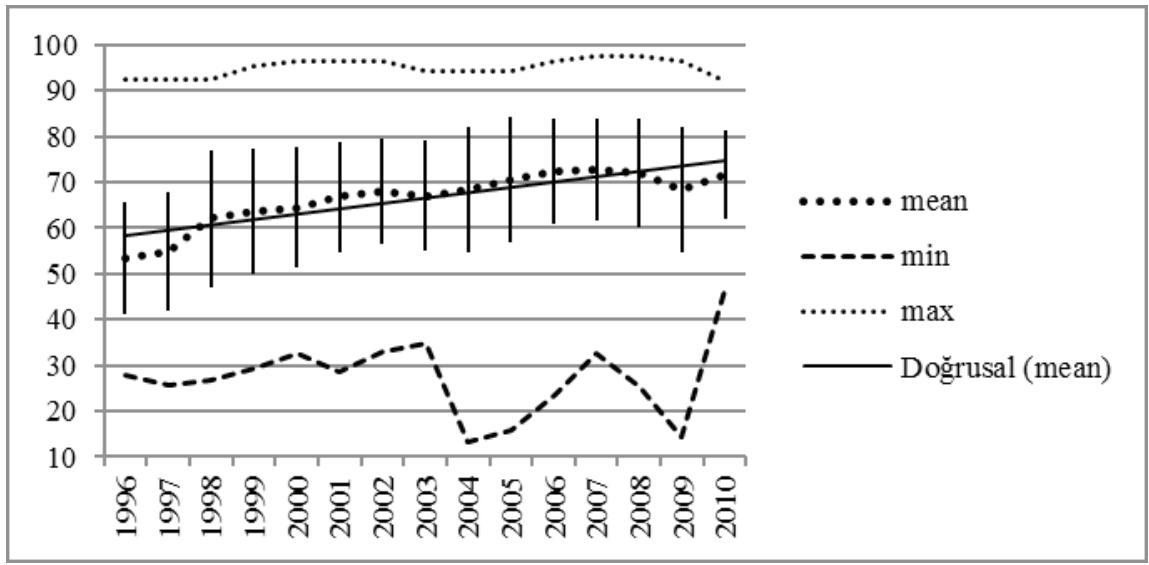

Source: Authors' Own Calculations

Average economic stability of seventy developing countries has a significant increasing trend that increased from 54 at 1996 to \% 72 at 2010 according to Figure 3. There is no significant trend in the standard deviation.

Figure 4: Average AQI for DC

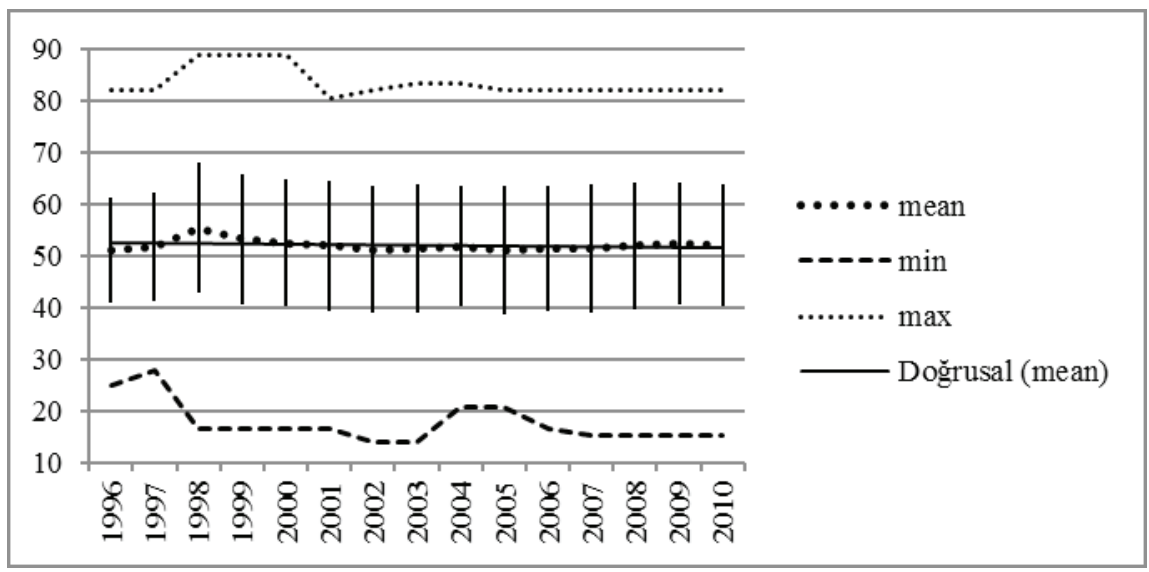

\section{Source: Authors' Own Calculations}

Average administrative quality of seventy developing countries has no significant trend that increased from 51 at 1996 to \% 52 at 2010 according to Figure 4. There is a slight increasing trend in the standard deviation, hence it seems that these countries experienced divergence with respect to this indicator. 
Figure 5: Average PVI for DC

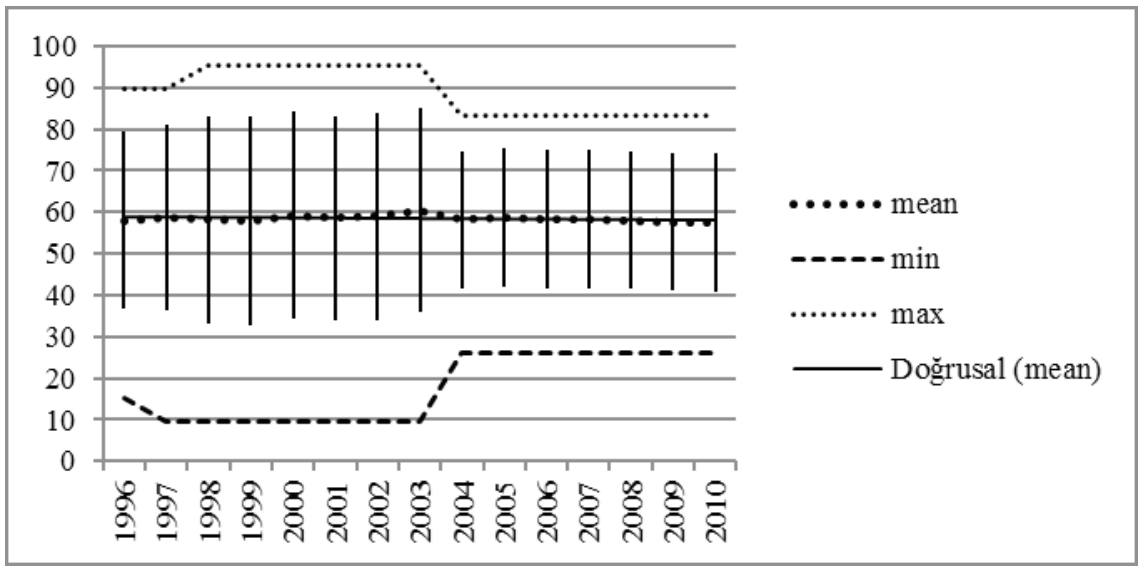

Source: Authors' Own Calculations

Average public voice of seventy developing countries has no significant trend that decreased from 58 at 1996 to \% 57 at 2010 according to Figure 5. There is a significant decreasing trend in the standard deviation; hence we can conclude that these countries experienced convergence with respect to this indicator. 


\subsection{Trend in Other Variables}

Figure 6: Other Variables I
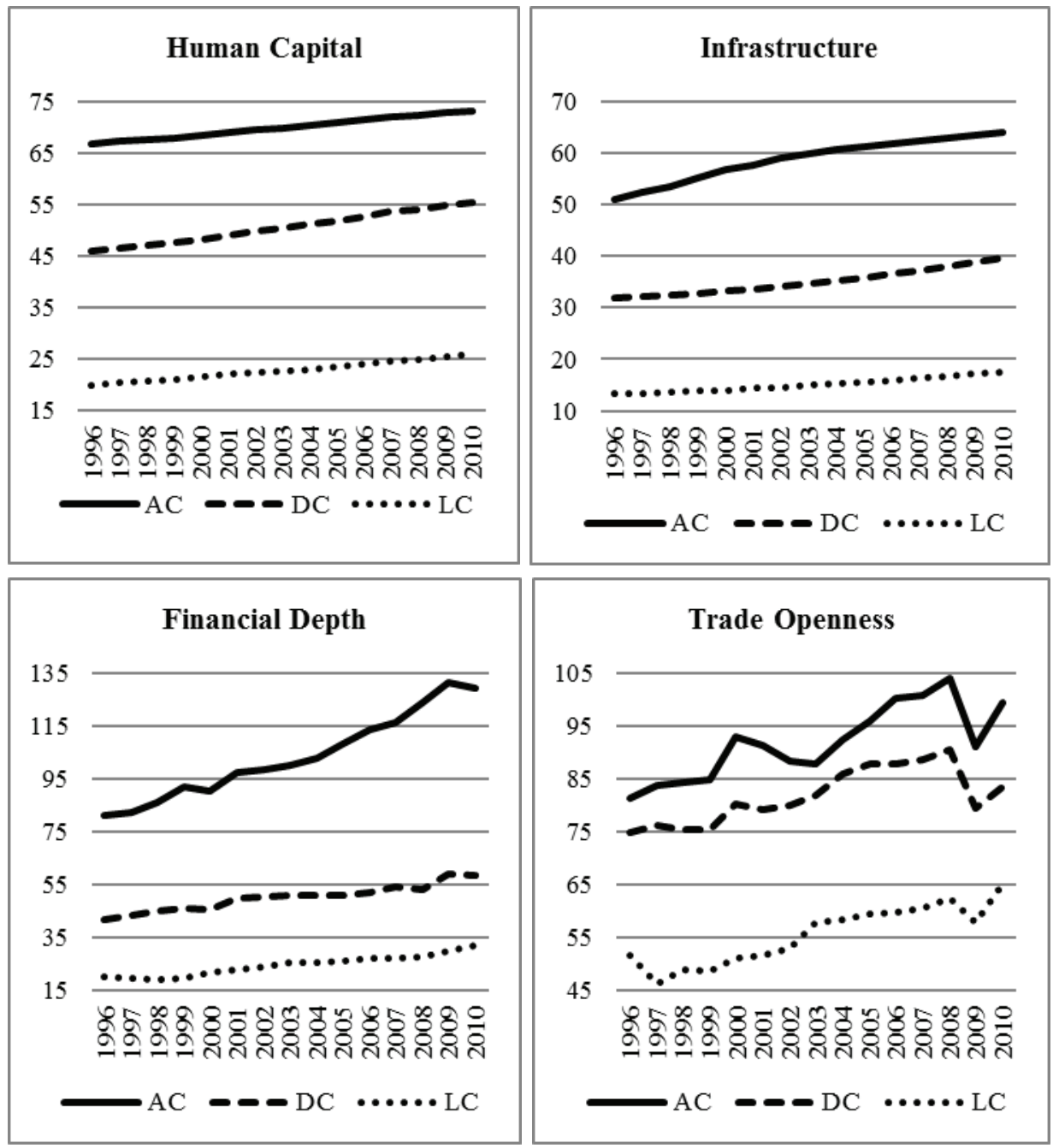

Source: Authors' Own Calculations

According to Figure 6, advanced countries have the highest performance and least developed countries have the worst performance for all the variables. Developing countries performs lower than advanced countries and higher than least developed countries as we expected, since these variables are indicators of long-term performance of these countries indicating their development level that cannot be easily manipulated by ongoing government policies. 
Figure 7: Other Variables II
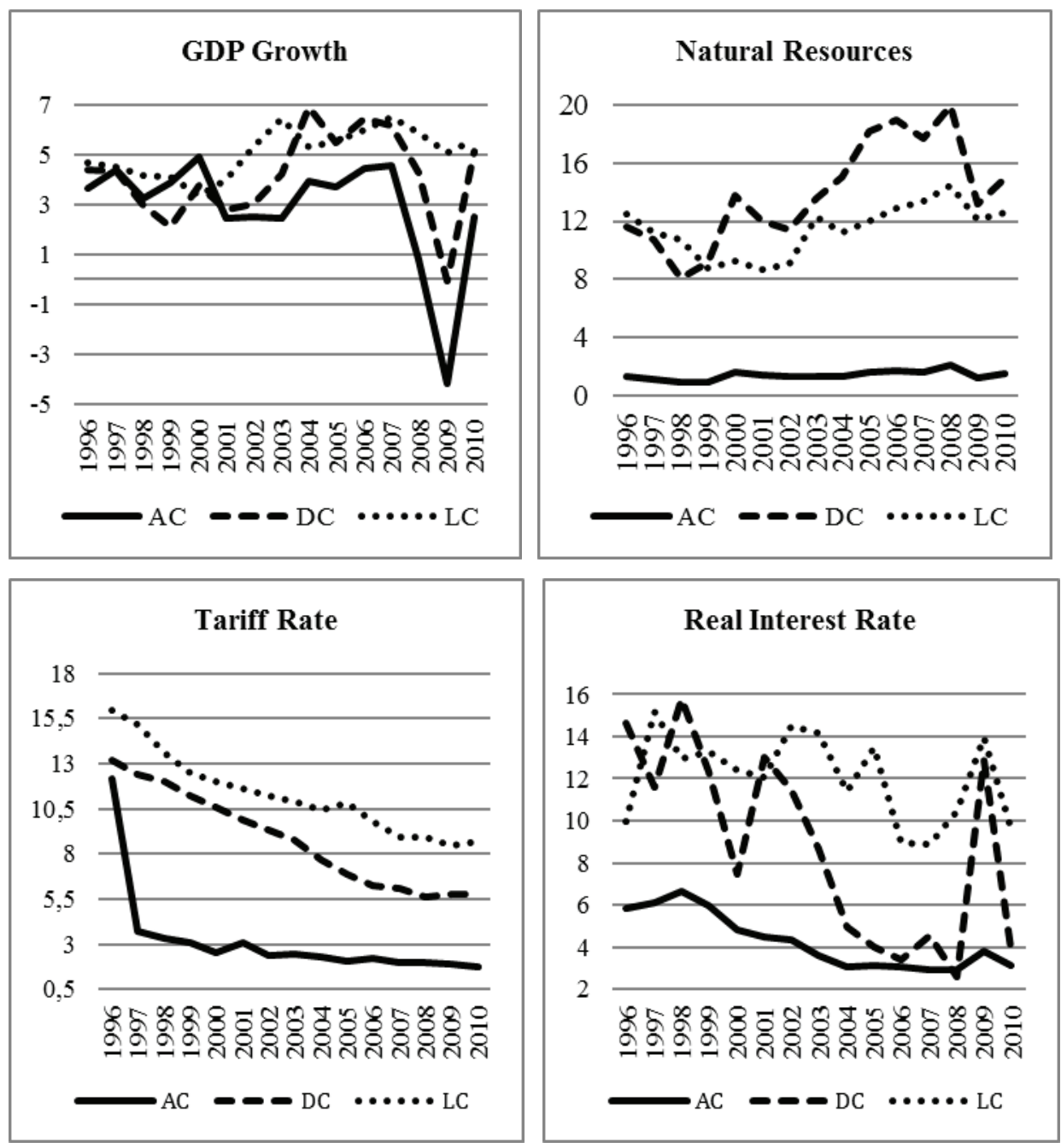

Source: Authors' Own Calculations

According to Figure 7, developing and least developed countries have growth performance higher than advanced countries supporting the convergence hypothesis since the trend is positive for developing and least developed countries, while it is negative for advanced countries. Also, advanced countries have lack of natural resources compared with developing and least developed countries. Tariff rates are the highest in least developed countries, high in developing countries and lower in advanced countries due to the degree of integration with the global economy. But there is a decreasing trend in all country clusters. Real interest rates highest in the least developed 
countries, high in developing countries and lower in advanced countries. But there is a decreasing trend in all country clusters.

\section{Empirical Analysis}

\section{I. System GMM Model}

Reduced form equations for Models 1-6;

(1.1) $\mathrm{FDI}_{\mathrm{it}}=\mathrm{aFDI}_{\mathrm{i}, \mathrm{t}-1}+\mathrm{b}_{1} \mathrm{BASE}_{\mathrm{it}}+\mathrm{b}_{2} \mathrm{MOT}_{\mathrm{it}}+\mathrm{e}_{\mathrm{it}}$

(1.2) $\mathrm{e}_{\mathrm{it}}=\mathrm{m}_{\mathrm{i}}+\mathrm{n}_{\mathrm{it}}$

Validity depends on the assumption that the $\mathrm{v}_{\mathrm{it}}$ is not serially correlated. But if the vit is serially correlated of order 1 then, the researcher would need to restrict the instrument set starting with third lag or longer. If the researcher finds second order correlation, he or she would need to start with even longer lags ${ }^{56}$.

(1.3) $\mathrm{E}\left(\mathrm{m}_{\mathrm{i}}\right)=\mathrm{E}\left(\mathrm{n}_{\mathrm{it}}\right)=\mathrm{E}\left(\mathrm{m}_{\mathrm{i}} \mathrm{n}_{\mathrm{it}}\right)=0$

(1.4) $\mathrm{DFDI}_{\mathrm{it}}=\mathrm{d} \mathrm{DFDI}_{\mathrm{i}, \mathrm{t}-\mathrm{t}}+\mathrm{fDBASE}_{\mathrm{it}}+1 \mathrm{DMOT}_{\mathrm{it}}+\mathrm{Dn}_{\mathrm{it}}$

(1.5) $\mathrm{E}\left[\Delta \mathrm{w}_{\mathrm{it}} \mu_{\mathrm{i}}\right]=0$

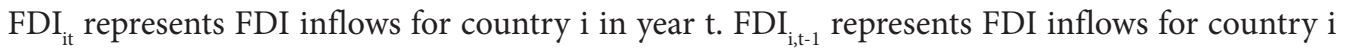
in year $\mathrm{t}-1$ to measure the oligopolistic reaction. $\mathrm{BASE}_{\mathrm{it}}$ represents base factors including, human capital, physical infrastructure, our four governance variables and two governance indicators from WGI ${ }^{57}$. MOT ${ }_{\text {it }}$ represents motivation factors as GDP growth, availability of natural resources, financial depth, trade openness, tariff rates and real interest rates for country i in year $t$.

Except Model 1.7 and Model 1.8 all the regressions include governance indicators as base factor. Model 1.7 incorporates human capital and Model 1.8 incorporates physical infrastructure as base factors. Since there exists high correlation between governance infrastructure, human capital and physical infrastructure, all these base factors regressed separately. All the regressions include lag of FDI inflows. All regressions include GDP growth as motivation factor. All other motivation factors are included in the regressions separately.

Reduced form equations for Model 7;

(2.1) $\mathrm{FDI}_{\mathrm{it}}=\mathrm{aFDI}_{\mathrm{i}, \mathrm{t}-1}+\mathrm{b}_{1} \mathrm{BASE}_{\mathrm{it}}+\mathrm{b}_{2} \mathrm{MOT}_{\mathrm{it}}+\mathrm{b}_{3} \mathrm{BASEMOT}_{\mathrm{it}}+\mathrm{e}_{\mathrm{it}}$

(2.2) $\mathrm{e}_{\mathrm{it}}=\mathrm{m}_{\mathrm{i}}+\mathrm{n}_{\mathrm{it}}$

(2.3) $\mathrm{E}\left(\mathrm{m}_{\mathrm{i}}\right)=\mathrm{E}\left(\mathrm{n}_{\mathrm{it}}\right)=\mathrm{E}\left(\mathrm{m}_{\mathrm{i}} \mathrm{n}_{\mathrm{it}}\right)=0$

(2.4) $\mathrm{DFDI}_{\mathrm{it}}=\mathrm{dDFDI}_{\mathrm{i}, \mathrm{t}-\mathrm{t}}+\mathrm{fDBASE}_{\mathrm{it}}+\mathrm{IDMOT}_{\mathrm{it}}+\mathrm{gDBASEMOT}_{\mathrm{it}}+\mathrm{Dn}_{\mathrm{it}}$

(2.5) $\mathrm{E}\left[\Delta \mathrm{w}_{\mathrm{it}} \mu_{\mathrm{i}}\right]=0$

56 Roodman, Ibid.

57 WGI, “The Worldwide Governance Indicators”, The World Bank, 2014. 
$\mathrm{FDI}_{\mathrm{it}}$ represents FDI inflows for country i in year t. FDI $_{\mathrm{i}, \mathrm{t}-1}$ represents FDI inflows for country $\mathrm{i}$ in year $\mathrm{t}-1$ to measure the oligopolistic reaction. $\mathrm{BASE}_{\mathrm{it}}$ represents one of our governance variables. $\mathrm{MOT}_{\text {it }}$ represents motivation factors, GDP growth or availability of natural resources for country $\mathrm{i}$ in year t. BASEMOT $\mathrm{B}_{\mathrm{it}}$ represents interaction of a base and motivation factor for country $\mathrm{i}$ in year $\mathrm{t}$.

\subsection{System GMM Analysis}

Table I: GMM Estimation Results I

\begin{tabular}{|c|c|c|c|c|c|c|c|c|}
\hline \multicolumn{9}{|c|}{ Dependent Variable: fdi } \\
\hline & Model 1.1 & Model 1.2 & Model 1.3 & Model 1.4 & Model 1.5 & Model 1.6 & Model 1.7 & Model 1.8 \\
\hline 1.fdi & $\begin{array}{l}0.604^{* * *} \\
(0.120)\end{array}$ & $\begin{array}{l}0.600^{* * *} \\
(0.103)\end{array}$ & $\begin{array}{l}0.416^{* *} \\
(0.189)\end{array}$ & $\begin{array}{l}0.606^{* * *} \\
(0.121)\end{array}$ & $\begin{array}{l}0.758^{* * *} \\
(0.074)\end{array}$ & $\begin{array}{l}0.625^{* * *} \\
(0.099)\end{array}$ & $\begin{array}{l}0.758^{\star * *} \\
(0.072)\end{array}$ & $\begin{array}{l}0.827^{\star * *} \\
(0.111)\end{array}$ \\
\hline psi & $\begin{array}{l}0.023^{* * *} \\
(0.008)\end{array}$ & & & & & & & \\
\hline esi & & $\begin{array}{l}0.019^{\star *} \\
(0.007)\end{array}$ & & & & & & \\
\hline aqi & & & $\begin{array}{l}0.050^{* *} \\
(0.020)\end{array}$ & & & & & \\
\hline pvi & & & & $\begin{array}{l}0.022^{* *} \\
(0.010)\end{array}$ & & & & \\
\hline psnv & & & & & $\begin{array}{l}0.893^{*} \\
(0.530)\end{array}$ & & & \\
\hline $\mathrm{va}$ & & & & & & $\begin{array}{l}0.911^{*} \\
(0.537)\end{array}$ & & \\
\hline gdpgr & $\begin{array}{l}0.136^{* *} \\
(0.058)\end{array}$ & $\begin{array}{l}0.136^{* *} \\
(0.054)\end{array}$ & $\begin{array}{l}0.167^{\star} \\
(0.086)\end{array}$ & $\begin{array}{l}0.190^{* * *} \\
(0.058)\end{array}$ & $\begin{array}{l}0.243^{\text {*} * *} \\
(0.052)\end{array}$ & $\begin{array}{l}0.317^{\text {}}(0.083) \\
(0.03)\end{array}$ & $\begin{array}{l}0.131^{* *} \\
(0.061)\end{array}$ & $\begin{array}{l}0.174^{* *} \\
(0.068)\end{array}$ \\
\hline humcap & & & & & & & $\begin{array}{l}0.010^{*} \\
(0.006)\end{array}$ & \\
\hline infra & & & & & & & & $\begin{array}{l}-0.008 \\
(0.011)\end{array}$ \\
\hline Prob $>F$ & 0.000 & 0.000 & 0.000 & 0.000 & 0.000 & 0.000 & 0.000 & 0.000 \\
\hline Countries & 70 & 70 & 70 & 70 & 70 & 70 & 70 & 70 \\
\hline Instruments & 24 & 23 & 24 & 24 & 25 & 18 & 24 & 27 \\
\hline Hansen & 0.839 & 0.671 & 0.616 & 0.585 & 0.463 & 0.560 & 0.665 & 0.178 \\
\hline $\mathrm{AR}(4)$ & 0.136 & 0.119 & 0.167 & 0.133 & 0.105 & 0.117 & 0.108 & 0.102 \\
\hline
\end{tabular}

\section{Source: Authors' Own Calculations}

Notes: The values in parenthesis are robust standard errors. ${ }^{* *},{ }^{* *}$ and ${ }^{\star}$ denote significance levels at $\% 1, \% 5$ and \% 10 respectively. $\mathrm{AR}(\#)$ is test for \#-order serial correlation in the \#-differenced residuals, under the null of no serial correlation. Hansen test of over-identification is under the null that all instruments are valid. All the independent variables except tariff are treated endogenously. Appropriate lags of endogenous variables were instrumented according to AR(\#) test of serial correlation 
Table 2: GMM Estimation Results II

\begin{tabular}{|c|c|c|c|c|c|c|}
\hline \multicolumn{7}{|c|}{ Dependent Variable: fdi } \\
\hline & Model 2.1 & Model 2.4 & Model 3.1 & Model 3.2 & Model 3.3 & Model 3.4 \\
\hline 1.fdi & $\begin{array}{l}0.355^{\star \star} \\
(0.166)\end{array}$ & $\begin{array}{l}0.451^{\star *} \\
(0.173)\end{array}$ & $\begin{array}{l}0.558^{* * *} \\
(0.119)\end{array}$ & $\begin{array}{l}0.615^{\star \star *} \\
(0.194)\end{array}$ & $\begin{array}{l}0.542^{* * *} \\
(0.130)\end{array}$ & $\begin{array}{l}0.470^{\star \star} \\
(0.181)\end{array}$ \\
\hline psi & $\begin{array}{l}0.034^{* * *} \\
(0.011)\end{array}$ & & $\begin{array}{l}0.020^{* *} \\
(0.010)\end{array}$ & & & \\
\hline esi & & & & $\begin{array}{l}0.020^{*} \\
(0.011)\end{array}$ & & \\
\hline aqi & & & & & $\begin{array}{l}0.036^{*} \\
(0.020)\end{array}$ & \\
\hline pvi & & $\begin{array}{l}0.034^{* *} \\
(0.017)\end{array}$ & & & & $\begin{array}{l}0.026^{*} \\
(0.014) \\
\end{array}$ \\
\hline gdpgr & $\begin{array}{l}0.152^{\star *} \\
(0.061)\end{array}$ & $\begin{array}{l}0.202^{* *} \\
(0.097)\end{array}$ & $\begin{array}{l}0.143^{* * *} \\
(0.048)\end{array}$ & \begin{tabular}{|l}
$0.163^{\star * *}$ \\
$(0.048)$
\end{tabular} & $\begin{array}{l}0.182^{\star * *} \\
(0.055)\end{array}$ & $\begin{array}{l}0.127^{\star *} \\
(0.057)\end{array}$ \\
\hline natural & $\begin{array}{l}-0.010 \\
(0.024)\end{array}$ & $\begin{array}{l}-0.019 \\
(0.033)\end{array}$ & & & & \\
\hline findep & & & $\begin{array}{l}0.002 \\
(0.016) \\
\end{array}$ & $\begin{array}{l}-0.010 \\
(0.014)\end{array}$ & $\begin{array}{l}0.002 \\
(0.022) \\
\end{array}$ & $\begin{array}{l}0.009 \\
(0.013)\end{array}$ \\
\hline Prob $>$ F & 0.000 & 0.000 & 0.000 & 0.000 & 0.000 & 0.000 \\
\hline Countries & 68 & 68 & 67 & 67 & 67 & 67 \\
\hline Instruments & 32 & 36 & 32 & 39 & 44 & 28 \\
\hline Hansen & 0.861 & 0.174 & 0.658 & 0.391 & 0.122 & 0.410 \\
\hline $\mathrm{AR}(4)$ & 0.247 & 0.178 & 0.151 & 0.134 & 0.135 & 0.179 \\
\hline
\end{tabular}

Source: Authors' Own Calculations

Notes: The values in parenthesis are robust standard errors. ${ }^{* *},{ }^{* *}$ and ${ }^{\star}$ denote significance levels at $\% 1, \% 5$ and $\% 10$ respectively. $\mathrm{AR}(\#)$ is test for \#-order serial correlation in the \#-differenced residuals, under the null of no serial correlation. Hansen test of over-identification is under the null that all instruments are valid. All the independent variables except tariff are treated endogenously. Appropriate lags of endogenous variables were instrumented according to AR(\#) test of serial correlation. 
Table 3: GMM Estimation Results III

\begin{tabular}{|c|c|c|c|c|c|c|c|}
\hline \multicolumn{8}{|c|}{ Dependent Variable: fdi } \\
\hline & Model 4.1 & Model 5.2 & Model 6.2 & Model 6.3 & Model 7.2 & Model 7.3 & Model 7.4 \\
\hline 1.fdi & $\begin{array}{l}0.524^{* *} \\
(0.246)\end{array}$ & \begin{tabular}{|l|}
$0.501^{* * *}$ \\
$(0.147)$
\end{tabular} & $\begin{array}{l}0.569^{* * *} \\
(0.129)\end{array}$ & $\begin{array}{l}0.369^{*} \\
(0.190)\end{array}$ & $\begin{array}{l}0.527^{* * *} \\
(0.129)\end{array}$ & $\begin{array}{l}0.602^{* * *} \\
(0.133)\end{array}$ & $\begin{array}{l}0.671^{\text {*** }} \\
(0.102)\end{array}$ \\
\hline psi & $\begin{array}{l}0.037^{\text {}} \\
(0.016)\end{array}$ & & & & & & \\
\hline esi & & $\begin{array}{l}0.020^{*} \\
(0.011)\end{array}$ & $\begin{array}{l}0.018^{\star} \\
(0.010)\end{array}$ & & $\begin{array}{l}0.016^{*} \\
(0.008)\end{array}$ & & \\
\hline aqi & & & & $\begin{array}{l}0.042^{*} \\
(0.025)\end{array}$ & & $\begin{array}{l}0.054^{* *} \\
(0.027)\end{array}$ & \\
\hline pvi & & & & & & & $\begin{array}{l}0.035^{\star *} \\
(0.017)\end{array}$ \\
\hline gdpgr & $\begin{array}{l}0.118^{\star} \\
(0.066)\end{array}$ & $\begin{array}{l}0.168^{* * *} \\
(0.059)\end{array}$ & $\begin{array}{l}0.191^{\star * *} \\
(0.072)\end{array}$ & $\begin{array}{l}0.260^{* * *} \\
(0.090)\end{array}$ & $\begin{array}{l}-0.388 \\
(0.212)\end{array}$ & \begin{tabular}{|l|}
-0.113 \\
$(0.102$
\end{tabular} & $\begin{array}{l}-0.116 \\
(0.126)\end{array}$ \\
\hline trop & \begin{tabular}{|l|}
-0.018 \\
$(0.015)$
\end{tabular} & & & & & & \\
\hline tariff & & $\begin{array}{l}-0.031 \\
(0.031)\end{array}$ & & & & & \\
\hline rint & & & $\begin{array}{l}-0.016 \\
(0.033)\end{array}$ & $\begin{array}{l}0.034 \\
(0.036)\end{array}$ & & & \\
\hline esigdpgr & & & & & $\begin{array}{l}0.006^{\star} \\
(0.003)\end{array}$ & & \\
\hline aqigdpgr & & & & & & $\begin{array}{l}0.005^{\star *} \\
(0.002)\end{array}$ & \\
\hline pvigdpgr & & & & & & & $\begin{array}{l}0.005^{\star *} \\
(0.002)\end{array}$ \\
\hline Prob $>F$ & 0.000 & 0.000 & 0.000 & 0.000 & 0.000 & 0.000 & 0.000 \\
\hline Countries & 67 & 65 & 57 & 57 & 70 & 70 & 70 \\
\hline Instruments & 24 & 33 & 43 & 32 & 44 & 40 & 48 \\
\hline Hansen & 0.348 & 0.121 & 0.203 & 0.463 & 0.182 & 0.151 & 0.175 \\
\hline $\mathrm{AR}(4)$ & 0.169 & 0.120 & 0.118 & 0.173 & 0.115 & 0.133 & 0.129 \\
\hline
\end{tabular}

Source: Authors' Own Calculations

Notes: The values in parenthesis are robust standard errors. ${ }^{* *},{ }^{* *}$ and ${ }^{*}$ denote significance levels at $\% 1, \% 5$ and $\% 10$ respectively. $\mathrm{AR}(\#)$ is test for \#-order serial correlation in the \#-differenced residuals, under the null of no serial correlation. Hansen test of over-identification is under the null that all instruments are valid. All the independent variables except tariff are treated endogenously. Appropriate lags of endogenous variables were instrumented according to AR(\#) test of serial correlation.

According to Tables 7.1-7.3, lag of FDI inflows have positive significant effect on current FDI inflows, which confirms oligopolistic reaction theory. Hence we can conclude that FDI is an "interactive kind of corporate behavior by which rival firms in an industry composed of a few 
large firms counter one another's moves by making similar moves themselves" ${ }^{58}$. The results of the study supports Knickerbocker ${ }^{59}$, Flowers ${ }^{60}$ and Kinoshita ${ }^{61}$ even they use other proxies to measure oligopolistic reaction. Estimation results also support Cheng and Kwan ${ }^{62}$, Noorbaksh et al. ${ }^{63}$, Biglaiser and DeRouen ${ }^{64}$, Biglaiser and Staats ${ }^{65}$, Cantah et al. ${ }^{66}$ in the sense that there exists a clustering effect for FDI, the increase (decrease) in FDI made in previous year leads to increase (decrease) in FDI made in current year.

Tables 7.1-7.3 reveal that all the governance variables have positive significant effect on FDI inflows. Hence better governance infrastructure attracts higher amount of FDI inflows in developing countries. Our results are robust in the sense that using two other governance variables from WGI confirms our results. Our results regarding governance variables are also robust in the sense that they have positive significant coefficients in each regression model. Our results support the findings of Globerman and Shapiro ${ }^{67}$, Buchanan et al. ${ }^{68}$ regarding governance infrastructure, Busse and Hefeker ${ }^{69}$ regarding political stability, Asiedu and Lien ${ }^{70}$ for economic stability, Globerman and Shapiro ${ }^{71}$, Busse and Hefeker ${ }^{72}$ regarding administrative quality, Busse and Hefeker ${ }^{73}$ regarding public voice.

According to Tables 7.1-7.3, market growth proxied by GDP growth has a positive significant effect on FDI inflows in developing countries. Hence we can conclude that rapidly growing foreign markets should attract foreign investors interested in expanding their stakes overseas. After all, the gains in output needed to meet rapidly increasing demand offer opportunities for economies of scale. Although MNCs may ignore scale considerations at current period, they

58 Knickerbocker, F. T., Oligopolistic Reaction and the Multinational Enterprise, Cambridge (MA), Harvard University Press, 1973, p.6.

59 Knickerbocker, Ibid.

60 E. B. Flowers, "Oligopolistic Reaction in European and Canadian Direct Investment in the United States", Journal of International Business Studies, Vol.7, 1976, pp.43-55.

61 Y. Kinoshita, "Firm Size and Determinants of Foreign Direct Investment", CERGE-EI Working Paper Series, No. $135,1998$.

62 L. K. Cheng, and Y. K.Kwan, "What are the Determinants of the Location of Foreign Direct Investment: The Chinese Experience”, Journal of International Economics, Vol.51, No.2, 2000, pp. 379-400.

63 F. Noorbakhsh, A. Paloni, and A. Youssef, "Human Capital and FDI Inflows to Developing Countries: New Empirical Evidence”, World Development, Vol.29, No.9, 2001, pp.1593-1610.

64 G. Biglaiser, and K. DeRouen, “The Expansion of Neoliberal Economic Reforms in Latin America”. International Studies Quarterly, Vol.48, No.3, 2004, pp.561-578.

65 G. Biglaiser, and J. L Staats, "Do Political Institutions Affect Foreign Direct Investment? A Survey of US Corporations in Latin America”. Political Research Quarterly, Vol.63, No.3, 2010, pp.508-522.

66 W. G. Cantah, E. A. Wiafe, and A. Adams, "Foreign Direct Investment and Trade Policy Openness in Sub-Saharan Africa”, MPRA Paper, No.58074, 2013.

67 Globerman and Shapiro, Global Foreign Direct Investment, Ibid.

68 B. G. Buchanan, Q. V. Le, and M. Rishi, "Foreign Direct Investment and Institutional Quality: Some Empirical Evidence", International Review of Financial Analysis, Vol.21, 2012, pp.81-89.

69 Busse and Hefeker, Ibid.

70 Asiedu and Lien, Ibid.

71 Globerman and Shapiro, Global Foreign Direct Investment, Ibid.

72 Busse and Hefeker, Ibid.

73 Busse and Hefeker, Ibid. 
want assurance that scale advantages will be possible in the future; so rapid growth gives this assurance $^{74}$. Our results support the findings of Noorbaksh et al. ${ }^{75}$.

We also found that in Table 7.1, human capital has a positive significant effect on FDI inflows in developing countries. Hence improvement in human capital attracts FDI in advanced countries. Our results support the findings of Narula ${ }^{76}$, Noorbaksh et al. ${ }^{77}$, Globerman and Shapiro ${ }^{78}$. Our findings in Table 7.1 show that physical infrastructure has no significant effect on FDI inflows in developing countries. Our results support the findings of Loree and Guisinger ${ }^{79}$.

Estimation results of Model 2.1 and 2.4 in Table 7.2 reveal that availability of natural resources has no significant effect on FDI inflows in developing countries. Inspecting the estimation results of Model 3.1, 3.2, 3.3 and 3.4 in Table 7.2, financial depth has no significant effect on FDI inflows in developing countries. Model 4.1 in Table 7.3 repots that trade openness has no significant effect on FDI inflows in developing countries. Our results support the findings of Globerman and Shapiro ${ }^{80}$, Busse and Hefeker ${ }^{81}$. Estimation results of Model 5.2 in Table 7.3 reveal that tariff rates have no significant effect on FDI inflows in developing countries. Inspecting the empirical findings of Models 6.1, 6.2, 6.3 and 6.4 in Table 7.3, real interest rate has no significant effect on FDI inflows in developing countries.

According to the estimation results of Models 7.2, 7.3 and 7.4 in Table 7.3, interaction term of governance indicators and GDP growth has a positive significant effect on FDI inflows in developing countries, even GDP growth has no significant effect in these models. It may be concluded that market growth, as a motivation factor alone, is not sufficient for MNCs to take FDI decision in developing countries if economic instability occurs or administrative quality, civil rights and liberties deteriorate in the host country.

\section{Conclusion}

Empirical findings show that improving all aspects of governance quality attracts more FDI inflows in developing countries. We may conclude that following economic policies aimed to increase GDP growth rate attract more FDI inflows. Investing in human capital to match up the necessary skill set demanded by MNCs seems to attract more FDI inflows. It seems that investing in physical infrastructure does not lead to higher amount of FDI inflows since infrastructure investment in developing countries are generally not planned strategically leading to wasting of resources and blended with political concerns to effect the voting behavior of the public. Finally,

Knickerbocker, Ibid.

Noorbaksh et al., Ibid.

76 R. Narula, Multinational Investment and Economic Structure: Globalization and Competitiveness, Routledge, London, 1996.

77 Noorbaksh et al., Ibid.

78 Globerman and Shapiro, Global Foreign Direct Investment, Ibid.

79 Loree and Guisinger, Ibid.

80 Globerman and Shapiro, Global Foreign Direct Investment, Ibid.

81 Busse and Hefeker, Ibid. 
it is found that a motivation factor alone whether GDP growth may not be sufficient for MNCs to take FDI decision since they also observe governance infrastructure in host countries and any deterioration in governance leads to decreasing amount of FDI inflows.

\section{References}

ASIEDU, E., "On the Determinants of Foreign Direct Investment to Developing Countries: Is Africa Different?", World Development, Vol.30, No.1, 2002, pp. 107-119.

ASIEDU, E., and LIEN, D., "Democracy, Foreign Direct Investment and Natural Resources", Journal of International Economics, Vol.84, No.1, 2011, pp. 99-111.

AYSAN, A. F., NABLI, M. K., and VAROUDAKIS, M. A. V., "Governance and Private Investment in the Middle East and North Africa”, CERDI, Etudes et Documents, E 27, 2006.

BELLOS, S., and SUBASAT, T., "Corruption and Foreign Direct Investment: A Panel Gravity Model Approach", Bulletin of Economic Research, Vol.64, No.4, 2012, pp. 565-574.

BELLOS, S., and SUBASAT, T., "Governance and Foreign Direct Investment: A Panel Gravity Model Approach”, International Review of Applied Economics, Vol.26, No.3, 2012, pp. 303-28.

BIGLAISER, G., and DEROUEN, K., "The Expansion of Neoliberal Economic Reforms in Latin America”, International Studies Quarterly, Vol.48, No.3, 2004, pp.561-578.

BIGLAISER, G., and STAATS, J. L., 2010, "Do Political Institutions Affect Foreign Direct Investment? A Survey of US Corporations in Latin America”, Political Research Quarterly, Vol.63, No.3, 2010, pp.508-522.

BUCHANAN, B. G., LE, Q. V., and RISHI, M., 2012, "Foreign Direct Investment and Institutional Quality: Some Empirical Evidence”, International Review of Financial Analysis, Vol.21, pp.81-89.

BUSSE, M., and HEFEKER, C., "Political Risk, Institutions and Foreign Direct Investment", European Journal of Political Economy, Vol.23, No.2, 2007, pp.397-415.

CANTAH, W. G., WIAFE, E. A., and ADAMS, A., "Foreign Direct Investment and Trade Policy Openness in Sub-Saharan Africa", MPRA Paper, No. 58074, 2013.

CHENG, L. K. and KWAN, Y. K., "What are the Determinants of the Location of Foreign Direct Investment: The Chinese Experience”, Journal of International Economics, Vol.51, No.2, 2000, pp.379-400.

DE MELLO, L.R., and SINCLAIR, M. T., "Foreign Direct Investment, Joint Ventures, and Endogenous Growth”, Discussion Paper, Department of Economics, University of Kent, 1995.

EGGER, P., and WINNER, H., "Evidence on Corruption as an Incentive for Foreign Direct Investment", European Journal of Political Economy, Vol.21, No.4, 2005, 932-952.

FLOWERS, E. B., "Oligopolistic Reaction in European and Canadian Direct Investment in the United States", Journal of International Business Studies, Vol.7, 1976, pp.43-55.

FRH, "Civil Liberties and Political Voice Index", Freedom House, Washington. D.C., 2012 <http://www. freedomhouse.org/>-(accessed 2 January 2012)

GLOBERMAN, S., and SHAPIRO, D., "Global Foreign Direct Investment Flows: The Role of Governance Infrastructure”, World Development, Vol.30, No.11, 2002, pp.1899-1919.

GLOBERMAN, S., and SHAPIRO, D., "Governance Infrastructure and US Foreign Direct Investment", Journal of International Business Studies, Vol.34, No.1, 2003, pp.19-39.

HABIB, M., and ZURAWICKI, L., "Corruption and Foreign Direct Investment", Journal of International Business Studies, Vol.33, No.2, 2002, pp.291-307.

ICRG, International Country Risk Guide, The PRS Group, New York, 2011. 
JADHAV, P., "Determinants of Foreign Direct Investment in BRICS Economies: Analysis of Economic, Institutional and Political Factor", Procedia-Social and Behavioral Sciences, 37, 2012, pp.5-14.

JUDE, C., and POP SILAGHI, M. I., "Foreign Direct Investment, Employment Creation and Economic Growth in CEE Countries. An Open Issue", Development, Energy, Environment, Economics, 1998, pp.352-356.

KAUFMANN, D., KRAAY, A., and ZOIDO-LOBATÓN, P., "Aggregating Governance Indicators", World Bank Publications, Vol. 2195, 1999.

KHAN, M. H., "Governance, Economic Growth and Development since the 1960s", DESA Working Paper, No. 54, 2007.

KINOSHITA, Y., "Firm Size and Determinants of Foreign Direct Investment”, CERGE-EI Working Paper Series, No. 135, 1998.

KNICKERBOCKER, F. T. Oligopolistic Reaction and the Multinational Enterprise, Cambridge (MA), Harvard University Press, 1973.

LA PORTA, R., LOPEZ-DE-SILANES, F., SHLEIFER, A., and VISHNY, R. W., "Legal Determinants of External Finance", Journal of Finance, Vol.52, No.3, 1997, pp.1131-1150.

MENGISTU, A., and ADHIKARY, B. K., "Does Good Governance Matter for FDI Inflows? Evidence from Asian Economies”, Asia Pasific Business Review, Vol.17, No.3, 2011, pp. 281-299.

NARULA, R., Multinational Investment and Economic Structure: Globalization and Competitiveness, Routledge, London, 1996.

NOORBAKHSH, F., PALONI, A., and Youssef, A., "Human Capital and FDI Inflows to Developing Countries: New Empirical Evidence”, World Development, Vol.29, No.9, 2001, pp.1593-1610.

OECD, Foreign Direct Investment for Development, OECD Publications Service, 2002.

ROODMAN, D., "How to Do Xtabond2: An Introduction to Difference and System GMM in Stata", Center for Global Development, Working Paper, No. 103, 2006.

SEKKAT, K., and VAROUDAKIS, M. A. V., Trade and Foreign Exchange Liberalization, Investment Climate, and FDI in the MENA Countries, World Bank, Middle East and North Africa, the Office of the Chief Economist, 2004.

STEIN, E., and DAUDE, C., "Institutions, Integration and the Location of Foreign Direct Investment", OECD Global Forum on International Investment, November 2001.

SUBASAT, T., and BELLOS, S., "Corruption and Foreign Direct Investment in Latin America: A Panel Gravity Model Approach", Journal of Management and Sustainability, Vol.3, No.4, 2013, pp.151-156.

TUMAN, J. P., and EMMERT, C. F., "The Political Economy of US Foreign Direct Investment in Latin America: A Reappraisal”, Latin American Research Review, Vol.39, No.3, 2004, pp.9-28.

UNCTAD, Unctad Statistic, United Nations, 2014. <http://unctadstat.unctad.org/wds/TableViewer/ tableView.aspx?ReportId=96740> (accessed 17 March 2014)

WALSH, J. P. and YU, J., “Determinants of Foreign Direct Investment: A Sectoral and Institutional Approach”, IMF Working Paper, WP/10/187, 2010.

WDI, "World Development Indicators", The World Bank, 2014. <http://data.worldbank.org/data-catalog/ world-development-indicators $>$ (accessed on 3 January 2014)

WEI, S. J., "How Taxing is Corruption on International Investors?", The Review of Economics and Statistics, Vol.82, No.1, 2000, pp.1-11.

WGI, “The Worldwide Governance Indicators”, The World Bank, 2014. <http://info.worldbank.org/ governance/wgi/index.aspx\#home> (accessed on 4 January 2014)

WHEELER, D. and MODY, A., "International Investment Location Decisions: The Case of US Firms", Journal of International Economics, Vol.33, No.1, 1992, pp.57-76. 
Adem GÖK • A. Suut DOĞRUEL

Appendix I: List of Developing Countries

\begin{tabular}{|r|r|r|r|}
\hline & \multicolumn{2}{|c|}{ Developing Countries (DC) } \\
\hline Albania & Dominican Republic & Kuwait & Romania \\
Algeria & Ecuador & Libya & Russia \\
Argentina & Egypt & Lithuania & Saudi Arabia \\
Armenia & Malaysia & South Africa \\
Bahrain & El Salvador & Mexico & Sri Lanka \\
Bolivia & Gabon & Moldova & Syria \\
Botswana & Ghana & Mongolia & Thailand \\
Brazil & Guatemala & Morocco & Trinidad \& Tobago \\
Brunei & Guyana & Namibia & Tunisia \\
Bulgaria & Honduras & Nicaragua & Turkey \\
Cameroon & Pungary & Pakistan & United Arab Emirates \\
Chile & India & Uanama & Ukraine \\
China & Indonesia & Uruguay \\
Colombia & Iran & Papua New Guinea & Venezuela \\
Congo & Iraq & Paraguay & Vietnam \\
Costa Rica & Jamaica & Peru & Zimbabwe \\
Côte d'Ivoire & Jordan & Philippines & Poland \\
Croatia & Kazakhstan & Qatar & \\
\hline
\end{tabular}




\section{Appendix 2: Data Sources}

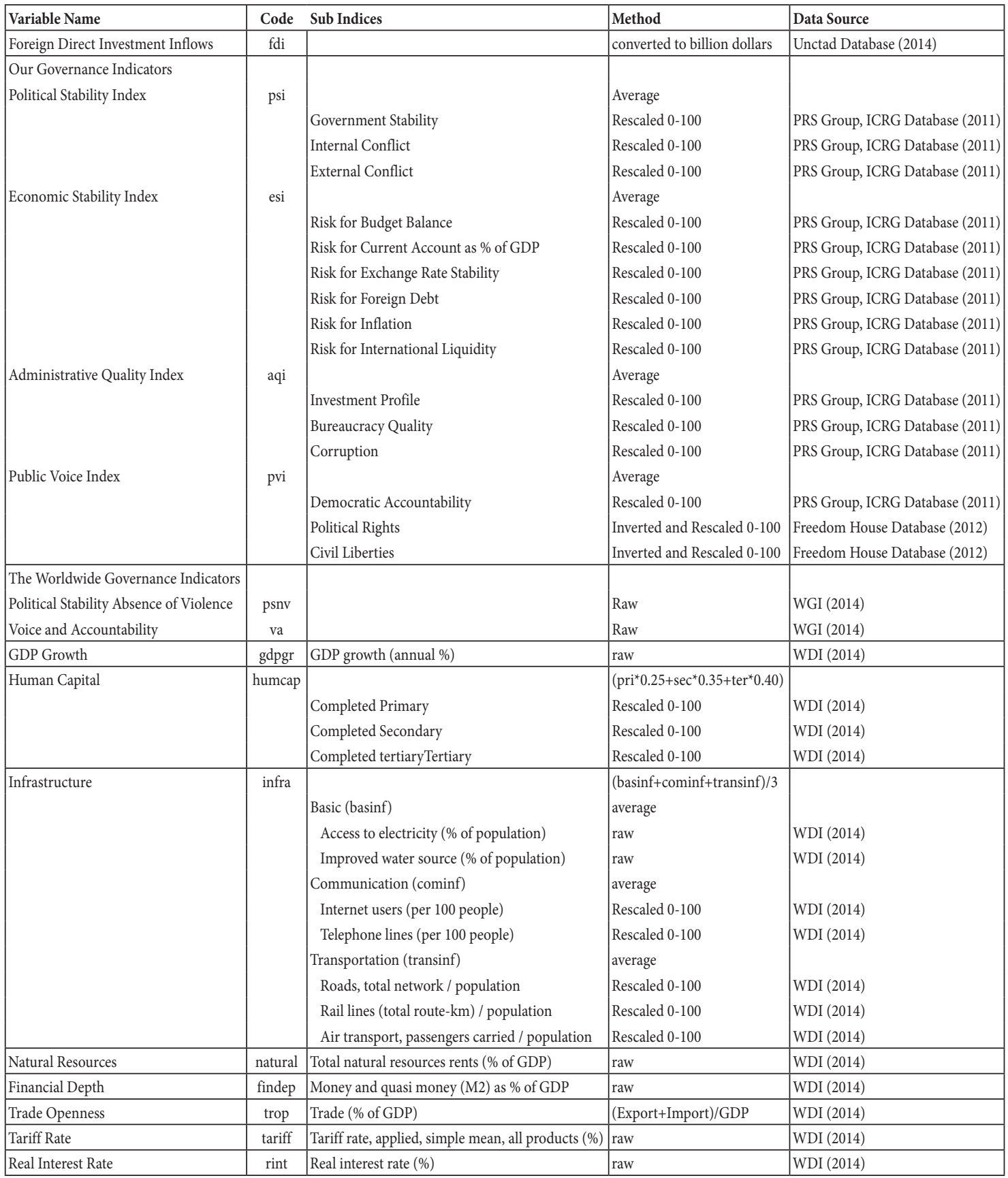


